\title{
Bat activity following repeated prescribed fire in the central Appalachians, USA
}

\author{
Lauren V Austin ${ }^{1}$, Alexander Silvis ${ }^{2}$, Michael S Muthersbaugh ${ }^{1}$, Karen E Powers ${ }^{3}$ and W Mark Ford ${ }^{4^{*}}$ (D)
}

\begin{abstract}
Background: To restore and manage fire-adapted forest communities in the central Appalachians, USA, land managers are now increasingly prioritizing use of prescribed fire. However, it is unclear how the reintroduction of fire following decades of suppression will affect bat communities, particularly where white-nose syndrome-related population declines of many cave-hibernating bat species have occurred. To address this concern, we monitored and compared bat activity in burned and unburned habitat across a temporal gradient in western Virginia.

Results: We found evidence for slightly positive fire effects on activity levels of the northern long-eared bat (Myotis septentrionalis [Trouessart, 1897]), Indiana bat (Myotis sodalis [Miller and Allen, 1928]), little brown bat (Myotis lucifugus [Le Conte, 1831]), big brown bat (Eptesicus fuscus [Palisot de Beauvois, 1796])/silver-haired bat (Lasionycteris noctivagans [Le Conte, 1831]) group, all high-frequency bats, and all bat species combined. We observed temporal effects only for the big brown bat, with a negative relationship between activity and time since fire.
\end{abstract}

Conclusion: Because response of bat activity was neutral to weakly positive relative to burned forest condition, our results suggest that bats are not a resource that would impede the use of this management tool in the central Appalachians.

Keywords: bat activity, central Appalachians, Chiroptera, prescribed fire, Virginia

\section{Resumen}

Antecedentes: Para restaurar y manejar las comunidades boscosas adaptadas al fuego en los Apalaches centrales de los EEUU, los administradores de recursos están ahora priorizando el uso de quemas prescriptas. Por supuesto, es todavía poco claro como la reintroducción del fuego luego de décadas de supresión va a afectar las comunidades de murciélagos, particularmente donde ha habido una declinación de las poblaciones de muchas especies de murciélagos invernadores de cuevas por efectos del síndrome de la nariz blanca. Para dilucidar esta preocupación, monitoreamos y comparamos la actividad de murciélagos en hábitats quemados y no quemados a través de un gradiente temporal en el oeste de Virginia.

(Continued on next page)

\footnotetext{
* Correspondence: wmford@vt.edu

${ }^{4}$ US Geological Survey; Virginia Cooperative Fish and Wildlife Research Unit,

106 Cheatham Hall, Blacksburg, Virginia 24061, USA

Full list of author information is available at the end of the article
} 
(Continued from previous page)

Resultados: Encontramos evidencias de pequeños efectos positivos del fuego en los niveles de actividad del murciélago orejudo norteño (Myotis septentrionalis [Trouessart, 1897]), del murciélago de Indiana (Myotis sodalis [Miller and Allen, 1928]), del pequeño murciélago marrón (Myotis lucifugus [Le Conte, 1831]), del gran murciélago marrón (Eptesicus fuscus [Palisot de Beauvois, 1796]) y del grupo de murciélagos de pelo plateado (Lasionycteris noctivagans [Le Conte, 1831]), todos murciélagos con alta frecuencia, y en todas las especies de murciélagos combinadas. Observamos efectos temporales solo para el gran murciélago marrón, con una relación negativa entre la actividad y el tiempo desde el fuego.

Conclusiones: Dado que la respuesta de la actividad de los murciélagos fue de neutra a escasamente positiva en relación a las quemas prescriptas del bosque, nuestros resultados sugieren que los murciélagos no son un recurso que pueda impedir el uso de esta herramienta de manejo en los Apalaches centrales.

\section{Background}

Fire occurrence was widespread in the eastern United States pre-European settlement due to Native American ignition and lightning strikes (Nowacki 2008), resulting in a landscape considerably modified and maintained by fire. As a result of the suppression era beginning in the 1920s, the frequency and intensity of fire decreased through the 1960s in the central Appalachians of western Virginia and elsewhere in the mid-Atlantic Highlands, resulting in profound forest composition shifts that now favor fire-intolerant species (Abrams 1992; Yarnell 1998). Through "mesophication" (Nowacki 2008), shade-intolerant and fire-dependent species fail to regenerate and self-replace as competing shade-tolerant and fire-intolerant species begin capturing canopy or light gaps in the forest stand (Kreye et al. 2013). These alterations result in an alternative stable forest condition whereby shading promotes cool, damp microclimates and the production of non-flammable fuels. As this progresses, it becomes increasingly difficult to reverse, and forests may be locked into a steady mesophytic state wherein only shade-tolerant, fire-intolerant plant species occur (Nowacki 2008). As such, land managers are prioritizing prescribed fire as a tool for maintaining current and transitioning fire-dependent communities in the East, particularly in the southern and central Appalachian Mountains (USDA Forest Service [US department of Agriculture Forest Service] 2006; Hessl et al. 2011).

Throughout North America, including the central Appalachians, bats currently are of great conservation concern (Carter and Ford 2002; Perry 2012) due to the impacts of white-nose syndrome (WNS; Francl et al. 2012, Reynolds et al. 2016) and the proliferation of wind energy development (Arnett 2013). Of the suite of bats in the region, the endangered Indiana bat (Myotis sodalis [Miller and Allen, 1928]; MYSO) and the threatened northern long-eared bat (Myotis septentrionalis [Trouessart, 1897]; MYSE) are two species potentially impacted by prescribed fire (Austin et al. 2018b). Prescribed fire use may alter non-hibernating season day-roosts, (i.e., trees and snags) or change foraging habitat conditions (Carter and Ford 2002; Perry 2012; Ford et al. 2016b; Silvis and Perry 2016b). Because there has been limited work examining the relationships of these and other bat species in the central Appalachians relative to the return of fire as a prescriptive tool, land managers are often challenged to show that burning is not additive in negative impacts to these already stressed species (Johnson et al. 2010b; Ford et al. 2016a).

Research on the short-term effects of fire on bats suggests that bats display species-specific responses to fire-modified vegetation (Owen et al. 2004; Cox et al. 2016; Austin et al. 2018a), with larger-bodied bats benefiting from vegetation clutter reduction that simplifies flight (Norberg 1985; Aldridge 1988). Snags in burned areas may be of higher quality for day-roosts because the newly created canopy gaps allow for increased canopy light penetration that aids in thermoregulation and expedites juvenile bat development (Zahn 1999; Boyles 2006; Johnson et al. 2009). Bats may even be robust to some roost tree loss (Silvis and Ford 2015), as may result from fire. Additionally, newly created roosts may offset loss (Ford et al. 2016a) as remaining trees are likely more conducive to roosting due to fire-modified cavity, bark conditions, and canopy characteristics (Perry 2012). However, Reilly et al. (2016) found that repeated prescribed fire in the southeastern Piedmont changed composition and structure of trees in the midstory but not in the overstory, indicating that foliage-roosting species may be less affected by fire. Many insect taxa, including Lepidoptera, that serve as prey for bats, also benefit from prescribed fire and associated increases in nectar-producing plants (Rudolph 2000) as well as new growth that provides a substrate on which to lay eggs and feed larva (Rudolph 2000; Evans et al. 2013).

Although most bat and fire research in central Appalachians has focused on day-roost ecology (Johnson et al. 2009, 2010b; Ford et al. 2016a, 2016b), acoustics have been used to monitor fire effects on bat activity (Johnson 2012). Cox et al. (2016) found that bat activity in the Cumberland Plateau was higher after spring and fall prescribed burns in savannah conditions than after spring 
and fall prescribed burns in woodlands. In the upper Piedmont and western Allegheny Hills, respectively, Loeb (2008) and Silvis and Gehrt (2016a) found that thinning and burning treatments yielded higher total bat activity than control stands. However, there has been relatively limited research on the effect of repeated prescribed fire relative to bats as used for restoration and maintenance of fire-dependent communities in the central and southern Appalachians. In the Chicago, Illinois, metropolitan area, repeated prescribed fire had a positive effect on bat activity (Smith 2010); and in a longleaf pine (Pinus palustris Miller)-wiregrass (Aristida stricta Michaux) ecosystem in Florida, higher bat activity was associated with sites that experienced short fire-return intervals (Armitage 2012).

With the continued spread of WNS, the severe population declines of many cave-dwelling species of bats that use forests for summer day-roosting and foraging, and the endangered status of MYSO and the threatened status of MYSE as regulatory drivers modifying land management activities, understanding of how practices such as prescribed fire affect bats is critical. Regionally, in the central Appalachians, managers are challenged to show that burn programs for other natural resource purposes will benefit bats or, at minimum, will not exacerbate population reductions from WNS (Ford et al. 2016a). To investigate this, we compared bat activity in burned and unburned forest habitat and examined edge effects associated with burning in the central Appalachians of western Virginia.
Previous research in the central Appalachians found strong species-specific responses to forest habitat and structural characteristics (Ford et al. 2005); thus, we predicted that bats would have distinct species-specific responses to repeated prescribed fire, as well as to the resulting fire-modified habitat and vegetation characteristics (Austin et al. 2018b).

\section{Methods}

\section{Study area}

We conducted our study on the Warm Springs Mountain Preserve (WSM) and adjacent portions of the George Washington National Forest (GWNF) cooperatively managed, in terms of fire application, by the United States Forest Service (USFS) and The Nature Conservancy (TNC). The area is within the western Ridge and Valley portion of the central Appalachian Mountains in Bath County, Virginia, USA. Depending on elevation and aspect, forests are predominately composed of pine-oak mixtures of white oak (Quercus alba Linnaeus), chestnut oak (Quercus prinus Linnaeus), northern red oak (Quercus rubra Linnaeus), pitch pine (Pinus rigida Miller), and table mountain pine (Pinus pungens Lamb.), with blueberries (Vaccinium spp. Linnaeus) and bear oak (Quercus illicifolia Wangenheim) in the understory. In fire-suppressed areas, forests also contain red maple (Acer rubrum Linnaeus) and eastern white pine (Pinus strobu sLinnaeus; Nowacki 2008), with mountain laurel (Kalmia latifolia Linnaeus) in the

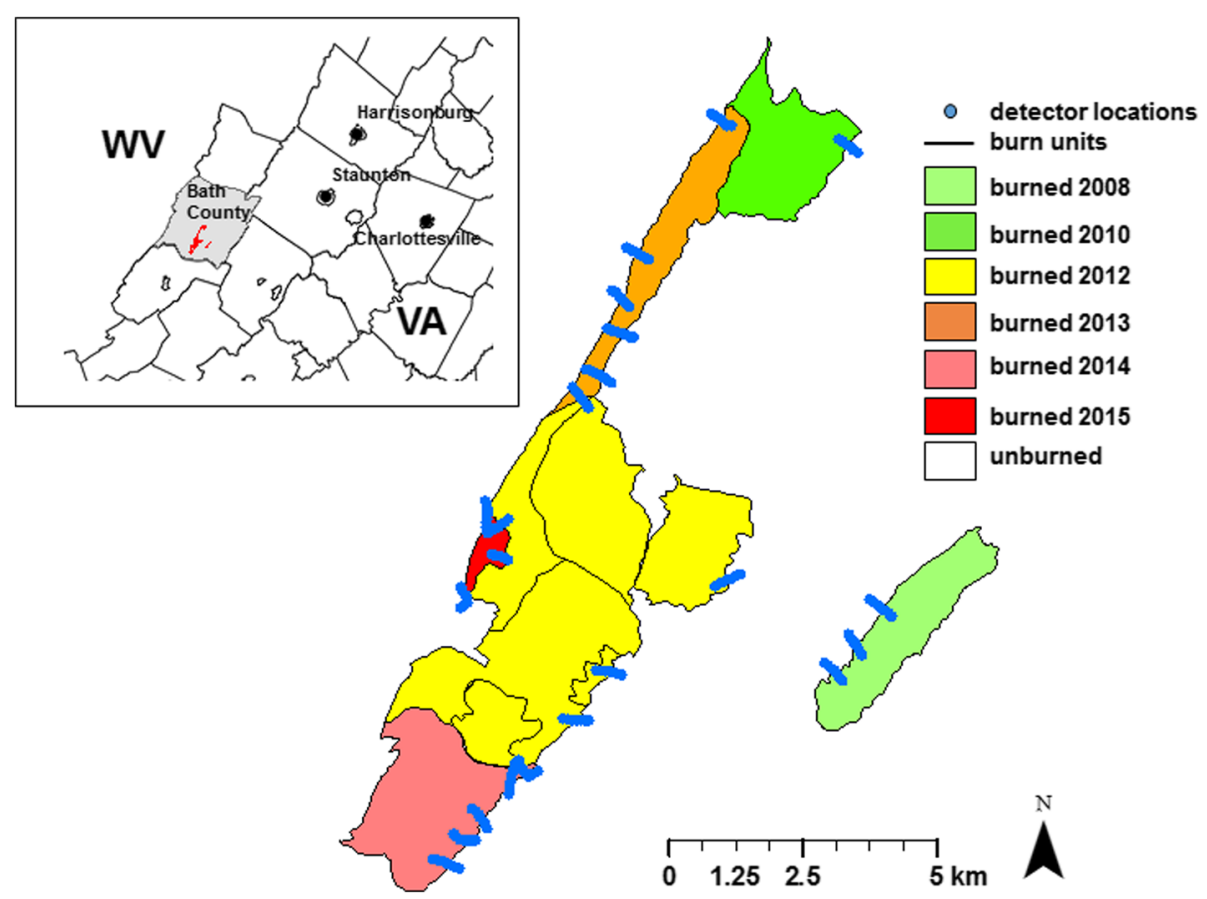

Fig. 1 Map of bat detector and burn plot locations (color coded by year last burned) for Warm Springs Mountain, Bath County, Virginia, USA, from 24 May to 15 August 2015. Insets show the location of Bath County within Virginia (VA) and the study area within Bath County. $W V=$ West Virginia 
Table 1 Competing $(\triangle \mathrm{QAIC} c<2)$ negative binomial mixed models describing bat activity, as well as null and global models, with random effects for site and transect, by species, at Warm Springs Mountain, Bath County, Virginia, USA, 24 May to 2 August 2015. We present the degrees of freedom (df), log likelihood (logLik), Akaike's Information Criteria for overdispersion and small sample size (QAICc), delta QAICc $(\triangle \mathrm{QAICc})$, and QAICc weight (Weight). *Data for Perimyotis subflavus were not overdispersed, thus estimates are from competing models with $\triangle \mathrm{AICC}<2$

\begin{tabular}{|c|c|c|c|c|c|c|}
\hline Species & Model(s) & df & logLik & QAICC & $\triangle \mathrm{QAICC}$ & Weight \\
\hline Eptesicus fuscus/Lasionycteris noctivagans & burn condition + elevation & 7 & -487.19 & 148.00 & 0.00 & 0.24 \\
\hline \multirow{4}{*}{ EPFU/LACl } & elevation & 5 & -507.47 & 149.00 & 1.01 & 0.15 \\
\hline & burn condition + burn quantity & 7 & -494.17 & 149.80 & 1.87 & 0.10 \\
\hline & null & 4 & -522.08 & 150.70 & 2.77 & 0.06 \\
\hline & global & 19 & -483.70 & 176.60 & 28.60 & 0.00 \\
\hline \multirow[t]{8}{*}{ Lasiurus borealis $L A B O$} & burn condition + canopy cover & 7 & -178.37 & 150.30 & 0.00 & 0.18 \\
\hline & burn condition & 6 & -181.87 & 150.70 & 0.38 & 0.15 \\
\hline & canopy cover & 5 & -186.05 & 151.60 & 1.30 & 0.10 \\
\hline & burn condition + burn quantity & 7 & -180.37 & 151.80 & 1.49 & 0.09 \\
\hline & burn condition + elevation & 7 & -180.72 & 152.00 & 1.75 & 0.08 \\
\hline & burn condition + basal area & 7 & -180.79 & 152.10 & 1.80 & 0.07 \\
\hline & null & 4 & -190.90 & 153.00 & 2.75 & 0.05 \\
\hline & global & 19 & -174.02 & 176.60 & 26.28 & 0.00 \\
\hline \multirow[t]{4}{*}{ Lasiurus cinereus LACI } & canopy cover & 5 & -162.28 & 155.20 & 0.00 & 0.56 \\
\hline & elevation & 5 & -164.08 & 156.80 & 1.58 & 0.25 \\
\hline & global & 19 & -147.94 & 176.60 & 21.37 & 0.00 \\
\hline & null & 4 & -176.28 & 165.30 & 10.13 & 0.00 \\
\hline \multirow[t]{5}{*}{ Myotis lucifugus MYLU } & burn condition + elevation & 7 & -179.90 & 149.90 & 0.00 & 0.24 \\
\hline & burn condition & 6 & -183.09 & 150.00 & 0.12 & 0.22 \\
\hline & burn condition + basal area & 7 & -182.51 & 151.80 & 1.93 & 0.09 \\
\hline & null & 4 & -195.41 & 154.70 & 4.85 & 0.02 \\
\hline & global & 19 & -176.05 & 176.60 & 26.69 & 0.00 \\
\hline \multirow[t]{3}{*}{ Myotis septentrionalis MYSE } & burn condition + elevation & 7 & -102.24 & 158.50 & 0.00 & 0.93 \\
\hline & global & 19 & -93.96 & 176.60 & 18.07 & 0.00 \\
\hline & null & 4 & -118.95 & 175.00 & 16.51 & 0.00 \\
\hline \multirow[t]{3}{*}{ Myotis sodalis MYSO } & burn condition + elevation & 7 & -132.29 & 152.30 & 0.00 & 0.69 \\
\hline & null & 4 & -146.18 & 159.90 & 7.58 & 0.02 \\
\hline & global & 19 & -127.17 & 176.60 & 24.29 & 0.00 \\
\hline \multirow[t]{8}{*}{ Perimyotis subflavus PESU* } & null & 4 & -67.73 & 143.70 & 0.00 & 0.16 \\
\hline & burn condition & 6 & -65.98 & 144.60 & 0.81 & 0.10 \\
\hline & aspect & 5 & -67.07 & 144.60 & 0.82 & 0.10 \\
\hline & elevation & 5 & -67.45 & 145.30 & 1.57 & 0.07 \\
\hline & burn condition + aspect & 7 & -65.29 & 145.40 & 1.64 & 0.07 \\
\hline & burn condition + elevation & 7 & -65.33 & 145.50 & 1.71 & 0.07 \\
\hline & canopy cover & 5 & -67.62 & 145.70 & 1.91 & 0.06 \\
\hline & global & 19 & -62.47 & 168.80 & 25.10 & 0.00 \\
\hline \multirow[t]{4}{*}{ High frequency } & burn condition + elevation & 7 & -272.75 & 149.50 & 0.00 & 0.26 \\
\hline & burn condition & 6 & -278.25 & 150.00 & 0.44 & 0.21 \\
\hline & null & 4 & -297.53 & 154.90 & 5.43 & 0.02 \\
\hline & global & 19 & -267.62 & 176.60 & 27.04 & 0.00 \\
\hline Total activity & burn condition + elevation & 7 & -524.61 & 147.80 & 0.00 & 0.23 \\
\hline
\end{tabular}


Table 1 Competing $(\triangle \mathrm{QAIC}<<2)$ negative binomial mixed models describing bat activity, as well as null and global models, with random effects for site and transect, by species, at Warm Springs Mountain, Bath County, Virginia, USA, 24 May to 2 August 2015. We present the degrees of freedom (df), log likelihood (logLik), Akaike's Information Criteria for overdispersion and small sample size (QAICC), delta QAICC $(\triangle \mathrm{QAICC})$, and QAICc weight (Weight). *Data for Perimyotis subflavus were not overdispersed, thus estimates are from competing models with $\triangle \mathrm{AICC}<2$ (Continued)

\begin{tabular}{llllrrr}
\hline Species & Model(s) & df & logLik & QAICc & $\Delta$ QAICC & Weight \\
\hline & elevation & 5 & -546.64 & 148.90 & 1.05 & 0.14 \\
& burn condition & 6 & -540.12 & 149.40 & 1.63 & 0.10 \\
& burn condition + burn quantity & 7 & -532.47 & 149.80 & 1.96 & 0.09 \\
& null & 4 & -560.64 & 150.20 & 2.37 & 0.07 \\
& global & 19 & -521.48 & 176.60 & 28.75 & 0.00 \\
\hline
\end{tabular}

understory. Elevation ranges from 500 to $1100 \mathrm{~m}$. In our study area, the USFS and TNC typically set prescribed fires in March and April of each year with aerial ignition (M. Smith, The Nature Conservancy, Warm Springs, Virginia, USA, personal communication). The matrix of variously aged burned plots (ranging in age from $<1$ to 8 years, and frequency from 1 to 3 burns) and unburned plots provides a diversity of forest stand conditions (Fig. 1). Much of the study area is proximal to karst topography with numerous known bat winter hibernacula that have been WNS positive and have experienced declining numbers of bats for several years (Reynolds et al. 2016).

\section{Data collection}

We recorded bat activity using acoustic detectors with SMM-U1 microphones (Songmeter ZC; Wildlife Acoustics, Maynard, Massachusetts, USA ${ }^{1}$ ) from 24 May through 2 August 2015. We programmed acoustic detectors to record data from 2000 to $0700 \mathrm{~h}$. We sampled burned and unburned sites equally over multiple nights using transects that extended $240 \mathrm{~m}$ perpendicularly into each management unit. Transects were $480 \mathrm{~m}$ long and contained seven acoustic detectors set $80 \mathrm{~m}$ apart, with the center detector placed at the interface (edge) of the burned and unburned habitat (Fig. 1). We spaced detectors $80 \mathrm{~m}$ apart to avoid detection of a single bat on two detectors simultaneously and to ensure relative independence among detectors. Edge sites were almost always near unimproved forest roads that served as compartment fire breaks on the area.

We used generalized random tessellation stratified sampling to spatially balance transect locations across the entire WSM study area, whereby placement was only constrained by a burned or unburned stand with enough area and width to contain a sampling transect covering the range of elevations where burns occurred (Philippi 2013). Following the protocol of Ford et al. (2005), we collected call data, site location, canopy closure, and basal area at the detector site. We derived elevation, aspect, and slope using digital elevation models within ArcMap 10.2.2 software (ESRI, Redlands, California, USA), available online through US Geological Survey (https://catalog.data.gov/ dataset/usgs-national-elevation-dataset-ned), and burn history and extent using burn layers provided by TNC.

\section{Data analysis}

\section{Bat call identification}

We identified calls using Kaleidoscope version 4.1.0, classifier version 3.1.0, at the sensitive setting (Wildlife Acoustics, Maynard, Massachusetts, USA). We used the default signal parameters in Kaleidoscope $(8-120 \mathrm{KHz}$ frequency range, 500 maximum inter-syllable gap, 2 minimum number of pulses, enhance with advanced signal processing) and specified nine individual species that were known to occur within our study region: big brown bats (Eptesicus fuscus [Palisot de Beauvois, 1796]); EPFU), hoary bats (Lasiurus cinereus [Palisot de Beauvois, 1796]; LACI), eastern red bat (Lasiurus borealis [Müller, 1776]; LABO), silver-haired bats (Lasionycterus noctivagans [Le Conte, 1831]; LANO), eastern small-footed bats (Myotis leibii [Audubon and Bachman, 1842]; MYLE), little brown bats (Myotis lucifugus[Le Conte, 1831]; MYLU), MYSE, MYSO, and tri-colored bats (Perimyotis subflavus [F. Cuvier, 1832]; PESU). Although there is considerable file-to-file variation among US Fish and Wildlife Service approved automated bat identification software programs used in the East, Nocera (2018) found that, when used at the nightly "total" per species level of resolution, Kaleidoscope provided comparable results to other programs and expert visual vetting. Furthermore, we visually validated calls to insure automated identification was correctly assigning ultrasonic recordings to bat species rather than insect or other extraneous noise (Austin et al. 2018b).

\section{Fire effects}

We created a set of 14 a priori negative binomial mixed models that incorporated burn and habitat variables to assess their effects on bat activity level (nightly counts by species by detector) as well as nested random effects for site and transect to account for the nested nature of sites within transects and nights within sites. These models-burn condition, burn condition + aspect, burn 
Table 2 Model averaged coefficients, unconditional standard errors (SE), and 95\% upper confidence interval (UCI) and lower confidence interval $(\mathrm{LCl})$ for competing $(\triangle \mathrm{QAIC}<2)$ negative binomial mixed models of bat activity by species for Warm Springs Mountain, Bath County, Virginia, USA, 24 May to 2 August 2015. *Myotis septentrionalis and Myotis sodalis were not model averaged and individual estimates, standard errors, and 95\% upper lower confidence intervals for the top negative binomial mixed model of bat activity are presented

\begin{tabular}{|c|c|c|c|c|c|}
\hline Species & Variable & Coefficient & SE & $\mathrm{LCl}$ & $\mathrm{UCl}$ \\
\hline \multirow{5}{*}{$\begin{array}{l}\text { Eptesicus fuscus/ } \\
\text { Lasionycteris noctivagans } \\
\text { EPFU/LANO }\end{array}$} & intercept & 0.65 & 0.41 & -0.15 & 1.49 \\
\hline & burn condition: burn & 0.57 & 0.45 & -0.35 & 1.44 \\
\hline & burn condition: edge & 2.10 & 1.35 & -0.68 & 4.74 \\
\hline & elevation & 0.70 & 0.38 & -0.04 & 1.45 \\
\hline & burn quantity & 0.18 & 0.37 & -0.55 & 0.90 \\
\hline \multirow[t]{7}{*}{ Lasiurus borealis $\mathrm{LABO}$} & intercept & -4.32 & 0.83 & -5.95 & -2.66 \\
\hline & burn condition: burn & 1.40 & 0.90 & -0.49 & 3.19 \\
\hline & burn condition: edge & 3.78 & 1.57 & 0.17 & 7.03 \\
\hline & canopy cover & -0.36 & 0.48 & -1.34 & 0.61 \\
\hline & burn quantity & 0.10 & 0.31 & -0.50 & 0.70 \\
\hline & elevation & 0.06 & 0.20 & -0.33 & 0.44 \\
\hline & basal area & -0.06 & 0.20 & -0.44 & 0.33 \\
\hline \multirow[t]{2}{*}{ Lasiurus cinereus LACI } & intercept & -1.57 & 0.31 & -2.19 & -0.95 \\
\hline & canopy cover & -0.54 & 0.38 & -1.28 & 0.21 \\
\hline \multirow[t]{5}{*}{ Myotis lucifugus MYLU } & intercept & -4.20 & 0.79 & -5.76 & -2.64 \\
\hline & burn condition: burn & 1.23 & 0.74 & -0.24 & 2.71 \\
\hline & burn condition: edge & 4.83 & 0.97 & 2.91 & 6.74 \\
\hline & elevation & 0.35 & 0.46 & -0.54 & 1.24 \\
\hline & basal area & -0.06 & 0.19 & -0.43 & 0.32 \\
\hline \multirow[t]{4}{*}{ Myotis septentrionalis MYSE* } & intercept & -5.27 & 1.03 & -7.84 & -3.59 \\
\hline & burn condition: burn & 2.10 & 0.98 & 0.18 & 4.02 \\
\hline & burn condition: edge & 4.99 & 1.05 & 3.16 & 7.49 \\
\hline & elevation & 1.26 & 0.35 & 0.62 & 2.04 \\
\hline \multirow[t]{3}{*}{ Myotis sodalis MYSO* } & intercept & -5.17 & 1.04 & -7.21 & -3.13 \\
\hline & burn condition: burn & 1.12 & 0.93 & -0.70 & 2.94 \\
\hline & burn condition: edge & 4.86 & 1.10 & 2.70 & 7.01 \\
\hline \multirow[t]{4}{*}{ High-frequency bats } & intercept & -2.30 & 0.48 & -3.26 & -1.35 \\
\hline & burn condition: burn & 1.26 & 0.54 & 0.20 & 2.33 \\
\hline & burn condition: edge & 4.18 & 0.67 & 2.86 & 5.51 \\
\hline & elevation & 0.43 & 0.41 & -0.39 & 1.22 \\
\hline \multirow[t]{5}{*}{ Total activity } & intercept & 0.82 & 0.41 & 0.02 & 1.70 \\
\hline & burn condition: burn & 0.70 & 0.46 & -0.29 & 1.61 \\
\hline & burn condition: edge & 2.45 & 1.28 & -0.38 & 5.00 \\
\hline & elevation & 0.58 & 0.42 & -0.27 & 1.41 \\
\hline & burn quantity & 0.13 & 0.32 & -0.49 & 0.75 \\
\hline
\end{tabular}

condition + slope, burn condition + basal area, burn condition + canopy cover, burn condition + burn year, burn condition + distance to edge, burn condition + burn quantity, aspect, elevation, basal area, canopy cover, distance to edge, burn quantity - as well as a null condition, were based on previous research that has shown that bat response by species varies by elevation and aspect (Ford et al. 2005), forest stand conditions such as basal area and stocking, and canopy closure in the central Appalachians (Owen et al. 2004). These are further modified by 
burn condition (burned, unburned, and edge between burned and unburned), burn history (year of burn), and burn quantity (area extent; Carter and Ford 2002, Loeb 2008, Silvis and Perry 2016b). We compared models representing competing hypotheses using an Information Theoretic approach by ranking models using Akaike's Information Criterion corrected for overdispersion and small sample size (QAICc; Burnham 2002). We identified a confidence set of models within $\triangle$ QAICc $<2$ as competing models. To account for uncertainty in the model selection process, we used package MuMIn (Barton 2016) in program $\mathrm{R}$ to obtain full model averaged estimates with a zero estimate when the parameter does not appear in the model, unconditional standard errors, and 95\% confidence intervals to assess individual variable effects on bat activity levels (Grueber et al. 2011; Symonds 2011).

\section{Results}

We collected data on 707 detector nights at 149 sites total for up to nine nights at each site. Uneven sampling periods among sites occurred due to periodic detector failures or black bear (Ursus americanus [Pallas, 1780]) damage. When visually examining calls, we identified a systematic error whereby insect noise was classified both as LACI and LABO calls. To address this issue, we visually examined all calls identified by Kaleidoscope using AnalookW v. 3.9f (Titley Electronics, Ballina, New South Wales, Australia) and removed erroneously identified insect noise. After removing noise, we repeated call analysis in Kaleidoscope to obtain corrected nightly counts by species. Kaleidoscope identified 24180 total call files, post visual noise removal, and assigned them to nine unique species: EPFU (10 039), LABO (2665), LACI (795), LANO (2836), MYLE (414), MYLU (3066), MYSE (1045), MYSO (3036), and PESU (284). For LANO, this represented an unusually high number of calls for the summer, as this species typically is caught only in May as it migrates through the state (Cryan 2003). However, post WNS, anecdotal reports of greater summer captures have been occurring (M. St. Germain, Virginia Tech Conservation Management Institute, Blacksburg, Virginia, USA, personal communication). Nonetheless, it was possible that many LANO calls were actually misclassified EPFU calls (Betts 1998; USFWS [US Fish and Wildlife Service] 2017); therefore, we combined all EPFU and LANO calls into one group and refered to them as EPFU/LANO. We also presented results for all high-frequency bats (Myotis spp. and PESU) combined to account for program identification uncertainty among Myotis species, and lastly, all bat species combined to examine fire and habitat effects on overall bat activity (O'Keefe et al. 2013, 2014).

Burn condition and elevation were the most important variables for explaining activity levels of EPFU/LANO,
MYLU, MYSE, MYSO, high-frequency bats, and total activity and had a positive effect on all species (Table 1; Table 2); the confidence interval for model-averaged burned habitat overlapped zero, indicating a neutral or marginal effect of burned habitat on EPFU/LANO, LABO, MYLU, MYSO, and total bat activity. However, within burn condition, edge had a positive effect on LABO, MYLU, MYSE MYSO, and all high-frequency bats combined (Fig. 2; Table 2). Burn quantity was included in the set of competing models for EPFU/LANO; the effect was marginally positive with confidence intervals overlapping zero. Basal area was also included in the set of competing models for MYLU; the effect was marginally negative with confidence intervals overlapping zero. Six models describing LABO activity contained combinations of burn condition, canopy cover, burn quantity, elevation, and basal area were competing (Table 2). Model-averaged confidence intervals overlapped zero for burned habitat, burn quantity, elevation, canopy cover, and basal area. The elevation model and the canopy cover model were the top models for LACI with canopy cover having a negative effect on activity and elevation having a slightly positive effect on activity. Confidence intervals for both variables overlapped zero. There were seven competing models that described PESU activity, with the top model being the null, indicating little evidence to suggest fire had an effect on this species (Table 2). Accordingly, we did not

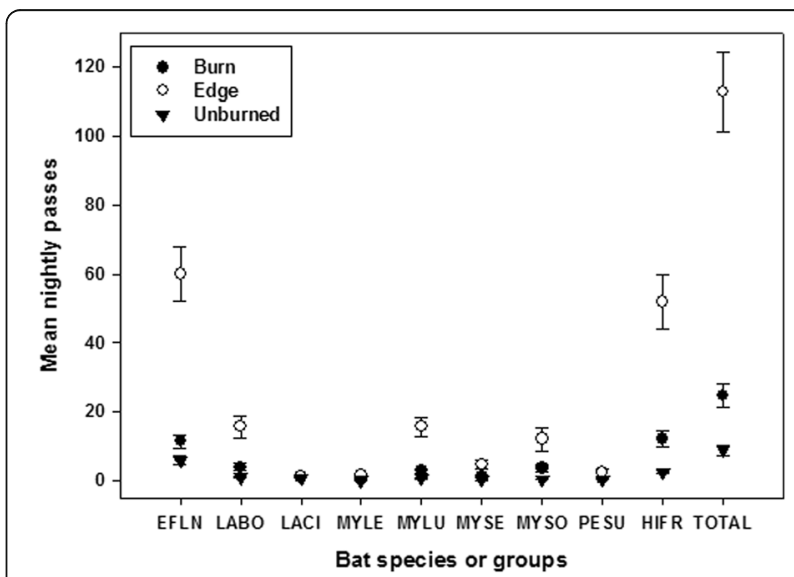

Fig. 2 Total mean nightly bat passes ( \pm standard error of the mean) across condition (burned, edge, and unburned) for Warm Springs Mountain, Bath County, Virginia, USA, 24 May to 15 August 2015. EFLN = big brown bat (Eptesicus fuscus)/silver-haired bat

(Lasionycterus noctivagans) group, LABO = eastern red bat (Lasiurus borealis), $\mathrm{LACl}=$ hoary bat (Lasiurus cinereus), MYLE = eastern smallfooted bat (Myotis leibii), MYLU = little brown bat (Myotis lucifugus), MYSE $=$ northern long-eared bat (Myotis septentrionalis), MYSO = Indiana bat (Myotis sodalis), PESU = tri-colored bat (Perimyotis subflavus), HIFR = LABO/MYLE/MYLU/MYSE/MYSO/PESU highfrequency group, and TOTAL = all bats 
model-average PESU results. Lastly, we were unable to analyze burn and habitat effects on MYLE due to model convergence error.

\section{Discussion}

We found some evidence for fire effects on MYSE, MYSO, MYLU, EPFU/LANO, high-frequency bats combined, and total activity. For all species and species groups, activity was the highest in edge habitat between burned and unburned portions of the surveyed transects and slightly higher in burned than unburned habitat. EPFU/ LANO, LABO, and total bat activity responded to multiple burns; at our study site,there had been up to three fires for some individual stands over a period of 812 years. As noted by earlier research, larger-bodied bats such as EPFU and LANO benefit from recent fires due to clutter reduction because it facilitates flight (Norberg 1985; Aldridge 1988; Brooks 2005). However, we observed some evidence that this was true for the smaller-bodied Myotis as well. Hutchinson and Sutherland (2005) found that $\geq 3$ fires were required over the course of eight years to achieve statistically significant differences in basal area of midstory trees and reductions in basal sprouting. Similarly, this suggests that multiple prescribed burns would be required before long-term benefits to larger-bodied bat species are evident (Austin et al. 2018a). Previous research in the central Appalachians (Austin et al. 2018a), as well as in the Coastal Plain of South Carolina (Ford et al. 2006; Hein and Castleberry 2009) has found that all bat activity, regardless of body size, is higher in corridors where flight efficiency is high for bats; it seems likely that this also occurs on WSM in and along the roads serving as fire breaks. Similar to riparian corridors (Rogers et al. 2006), the creation of fire breaks may benefit bats by providing efficient travel pathways connecting roosting and foraging areas. These areas of concentrated activity may offer potential bat monitoring locations to assess fire effects in this area in the future.

Nonetheless, both MYLU and MYSO displayed only slight positive to neutral responses to prescribed fire. These species, while considered more clutter-adapted than LABO and less clutter-tolerant than MYSE (Broders and Findlay 2004; Brooks 2005; Broders et al. 2006), are likely tolerant of a wide range of forest conditions. However, it is widely accepted that higher acoustic activity indicates better habitat conditions (Johnson et al. 2010a; Coleman et al. 2014). For example, Brooks (2005) noted that MYLU was present across all habitat types in New England. Moreover, in bottomland hardwood forests of Illinois (Carter 2005) and in the agriculture landscape of central Ohio (Kniowski 2014), MYSO readily utilized bottomland habitat, an area likely unaffected by fire, for roosting or foraging.

The clutter-adapted MYSE, a gleaning species, displayed a positive response to prescribed fire.
Immediate effects of a single fire, post suppression, include mortality of understory vegetation and small trees (although dependent on fire severity and slope position), and prolific basal sprouting shortly post fire (Elliott et al. 1999). In the absence of midstory clutter, basal sprouts may provide additional substrate for gleaning insects (Ratcliffe 2003). Indeed, Silvis and Gehrt (2016a); Silvis and Perry (2016b) found that Myotis were positively related to low-strata vegetative clutter. Several studies also have documented positive fire effects on MYSE roosting habitat (Johnson et al. 2009; Lacki et al. 2009; Ford et al. 2016a). In all burn conditions, activity had a slightly positive relationship with increased elevation. Because burn intensity is greater on upper slopes (Mladenoff 1999), reductions in clutter that improve foraging condition may have negated previously negative relationships with bat activity and increasing elevation in the central Appalachians at elevations where oak-dominated types are replaced by northern hardwood to the west on the Allegheny Plareau (Ford et al. 2005; Ford et al. 2016b).

Similar to our findings, Ford et al. (2005) also documented a positive relationship between LACI activity and minimum canopy gap width in the central Appalachians. Previous research has found that LACI use rapid, straight flight and low-attenuating, high amplitude echolocation to pursue prey in open habitats (Barclay 1985).

Our results show lack of support for connection between most burn and habitat variables and LABO activity with the exception of edge habitat between the burned and unburned stands. In the central Appalachians, LABO tend to be forest habitat generalists (Hutchinson 1999; Ford et al. 2005; Austin et al. 2018b). Ford et al. (2005) documented a positive trend with minimum canopy gap size for LABO. Similarly, LABO in our study area used the woods' roads present at our edge sites between burned and unburned stands. Whether in burned forests or unburned forests, woods' roads provide linear canopy openings or, at minimum, a less cluttered corridor when a covering canopy was present where LABO activity often is high (Estrada and Coates-Estrada 2001; Ford et al. 2006; Hein and Castleberry 2009; Austin et al. 2018a).

\section{Conclusion}

In the central Appalachians, fire is used for conservation of fire-dependent, oak-dominant communities and to promote the montane pine systems, as well as to help land managers meet other stewardship goals (i.e., preservation of biodiversity and control of invasive plant species). Our research helps to elucidate effects of repeated prescribed fire in the central Appalachians in the summer. Overall, we found weak positive to neutral effects of fire on bats. Small sample sizes for species such as PESU and MYLE resulting from WNS-related population declines (Frick 
et al. 2010; Ford et al. 2011; Francl et al. 2012) further limit the inferences we can draw about fire effects on bats in this landscape. Further research is needed to determine whether these negligible impacts extend to critical fall swarm and spring emergence periods when habitat associations of bats are less well understood (Muthersbaugh 2018). Relative to most of the GWNF, the WSM landscape has a higher rate of prescribed fire both spatially and temporally. Indeed, despite prioritization of prescribed burning regionally (Brose 2014), burned land comprises a small percentage of public lands overall in the central Appalachians (Ford et al. 2016a). The bat activity response we observed at WSM suggests that bat presence should not serve as an impediment for burn programs on the central Appalachian landscape.

\section{Endnotes}

${ }^{1}$ The use of any trade, product, or firm names does not imply endorsement by the US government.

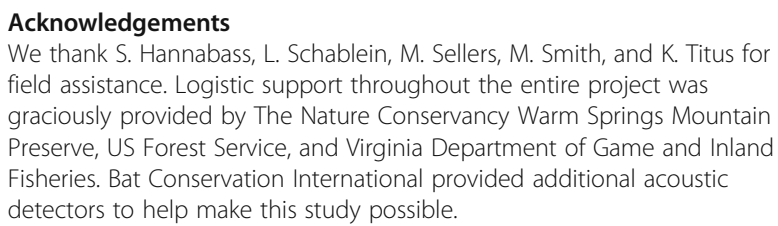
field assistance. Logistic support throughout the entire project was graciously provided by The Nature Conservancy Warm Springs Mountain Preserve, US Forest Service, and Virginia Department of Game and Inland Fisheries. Bat Conservation International provided additional acoustic detectors to help make this study possible.

\section{Funding}

Funding was provided was provided by the Joint Fire Sciences Program's 14-1-05 Compatibility of Fire and Fuel Treatments with Threatened and Endangered Bats call through cooperative agreement G14 AC0016 to Virginia Polytechnic Institute and State University.

\section{Availability of data and materials}

Because these data contain specific coordinates of the presence of federally threatened and endangered species and site-level activity levels, we will not openly provide the data. Rather, those seeking the data can make a formal request to the corresponding author, Virginia Department of Game and Inland Fisheries, and US Fish and Wildlife Service, Virginia Field Office, for consideration.

\section{Authors' contributions \\ WMF and KEP designed the project and provided project management oversight. LVA and MSM collected data, performed data analysis, and provided data interpretation. AS assisted with data analysis. LVA prepared the manuscript and all other authors provided editorial assistance. All authors read and approved the final manuscript.}

\section{Ethics approval}

Use of wild animals as test subjects was approved by the Virginia Tech Institutional Animal Care and Use Committee, protocol 14-014-FWS.

\section{Consent for publication}

Not applicable.

\section{Competing interests}

The authors declare that they have no competing interests.

\section{Publisher's Note}

Springer Nature remains neutral with regard to jurisdictional claims in published maps and institutional affiliations.

\section{Author details}

'Department of Fisheries and Wildlife Conservation, Virginia Polytechnic Institute and State University, 106 Cheatham Hall, Blacksburg, Virginia 24061, USA. ${ }^{2}$ RES Inc., 5367 Telephone Road, Warrenton, Virginia 20187, USA.

${ }^{3}$ Biology Department, Radford University, Box 6931, Radford, Virginia 24142, USA. ${ }^{4}$ US Geological Survey; Virginia Cooperative Fish and Wildlife Research Unit, 106 Cheatham Hall, Blacksburg, Virginia 24061, USA.

Received: 21 March 2018 Accepted: 18 September 2018

Published online: 27 December 2018

\section{References}

Abrams, M.D. 1992. Fire and the development of oak forests. BioScience 42: 346-353 https://doi.org/10.2307/1311781.

Aldridge, H.D.J.N., and R.M. Brigham. 1988. Load carrying and maneuverability in an insectivorous bat: a test of the $5 \%$ "rule" of radio-telemetry. Journal of Mammalogy 69: 379-382 https://doi.org/10.2307/1381393.

Armitage, D.W., and H.K. Ober. 2012. The effects of prescribed fire on bat communities in the longleaf pine sandhills ecosystem. Journal of Mammalogy 93: 102-114 https://doi.org/10.1644/11-MAMM-A-169.1.

Arnett, E.B., and E.F. Baerwald. 2013. Impacts of wind energy development on bats: implications for conservation. In Bat Evolution, Ecology, and Conservation, ed. R.A. Adams, 435-456. New York: Springer.

Austin, L.V., A. Silvis, W.M. Ford, M.S. Muthersbaugh, and K.E. Powers. 2018. Bat activity following restoration prescribed burning in the central Appalachian upland and riparian habitats. Natural Areas Journal 38: 183-195 https://doi. org/10.3375/043.038.0208.

Austin, L.V., A. Silvis, W.M. Ford, and K.E. Powers. 2018a. Effects of historic wildfire and prescribed fire on site occupancy of bats in Shenandoah National Park, Virginia, USA. Journal of Forest Research in press.

Barclay, R.M.R. 1985. Long- versus short-range foraging strategies of hoary (Lasiurus cinereus) and silver-haired (Lasionycteris noctivagans) bats and the consequences for prey selection. Canadian Journal of Zoology 63: 2507-2515 https://doi.org/10.1139/z85-371.

Barton, K 2016. MuMIn: multi-model inference. https://cran.r-project.org/web/ packages/MuMIn/index.html. Accessed 12 Apr 2017.

Betts, B.J. 1998. Effects of interindividual variation in echolocation calls on identification of big brown and silver-haired bats. Journal of Wildlife Management 62: 1003-1010 https://doi.org/10.2307/3802553.

Boyles, J.G., and D.P. Aubrey. 2006. Managing forests with prescribed fire: implications for a cavity-dwelling bat species. Forest Ecology and Management 222: 108-115 https://doi.org/10.1016/j.foreco.2005.09.024.

Broders, H.G., C.S. Findlay, and L. Zheng. 2004. Effects of clutter on echolocation call structure of Myotis septentrionalis and M. lucifugus. Journal of Mammalogy 85: 273-281 https://doi.org/10.1644/BWG-102.

Broders, H.G., G.J. Forbes, S. Woodley, and I.D. Thompson. 2006. Range extent and stand selection for roosting and foraging in forest-dwelling northern longeared bats and little brown bats in the Greater Fundy ecosystem, New Brunswick. Journal of Wildlife Management 70: 1174-1184.

Brooks, R.T., and W.M. Ford. 2005. Bat activity in a forest landscape of central Massachusetts. Northeastern Naturalist 12: 447-462.

Brose, P.H. 2014. Development of prescribed fire as a silvicultural tool for the upland oak forests of the eastern United States. Journal of Forestry 112 (5): 525-533 https://doi.org/10.5849/jof.13-088.

Burnham, K.P., and D.R. Anderson. 2002. Model selection and multimodel inference: a practical information-theoretic approach. second ed. New York: Springer.

Carter, T.C., and G.A. Feldhamer. 2005. Roost tree use by maternity colonies of Indiana bats and northern long-eared bats in southern Illinois. Forest Ecology and Management 219: 259-268 https://doi.org/10.1016/j.foreco.2005.08.049.

Carter, T.C., W.M. Ford, and M.A. Menzel. 2002. Fire and bats in the Southeast and Mid-Atlantic: more questions than answers? In Proceedings: the role of fire for nongame wildlife management and community restoration: traditional uses and new directions. USDA Forest Service General Technical Report NE-288, ed. W.M. Ford, K.R. Russell, and C.E. Moorman, 139-143. Newtown Square: Northeastern Research Station.

Coleman, L.S., W.M. Ford, C.A. Dobony, and E.R. Britzke. 2014. Comparison of radio-telemetric home-range analysis and acoustic detection for little brown bat habitat evaluation. Northeastern Naturalist 21: 431-445 https://doi.org/10. 1656/045.021.0309.

Cox, M.R. E.V. Willcox, P.D. Keyser, and A.L. Vander Yacht. 2016. Bat response to prescribed fire and overstory thinning in hardwood forest on the Cumberland 
Plateau, Tennessee. Forest Ecology and Management 359: 221-231 https:/doi. org/10.1016/j.foreco.2015.09.048.

Cryan, P.M. 2003. Seasonal distribution of migratory tree bats (Lasiurus and Lasionycteris) in North America. Journal of Mammalogy 84: 579-593 https:// doi.org/10.1644/1545-1542(2003)084\%3C0579:SDOMTB\%3E2.0.CO;2.

Elliott, K.., R.L. Hendrick, A.E. Major, J.M. Vose, and W.T. Swank. 1999. Vegetation dynamics after a prescribed fire in the southern Appalachians. Forest Ecology and Management 114: 199-213 https://doi.org/10.1016/S0378-1127(98)00351-X.

Estrada, A., and R. Coates-Estrada. 2001. Bat species richness in live fences and in corridors of residual rain forest vegetation at Los Tuxtlas, Mexico. Ecography 24: 94-102 https://doi.org/10.1034/j.1600-0587.2001.240111.x.

Evans, T.R., C.J.M. Musters, E.D. Cashatt, and G.R. de Snoo. 2013. Lepidoptera pest species response to mid-summer fire. Fire Ecology 9: 25-32 https://doi.org/10 4996/fireecology.0903025.

Ford, W.M., E.R. Britzke, C.A. Dobony, J.L. Rodrigue, and J.B. Johnson. 2011. Patterns of acoustical activity of bats prior to and following white-nose syndrome occurrence. Journal of Fish and Wildlife Management 2: 125-134 https://doi.org/10.3996/042011-JFWM-027.

Ford, W.M., J.M. Menzel, M.A. Menzel, J.W. Edwards, and J.C. Kilgo. 2006. Presence and absence of bats across habitat scales in the upper Coastal Plain of South Carolina. Journal of Wildlife Management 70: 1200-1209.

Ford, W.M., M.A. Menzel, J.L. Rodrigue, J.M. Menzel, and J.B. Johnson. 2005. Relating bat species presence to simple habitat measures in a central Appalachian forest. Biological Conservation 126: 528-539 https://doi.org/10. 1016/.biocon.2005.07.003.

Ford, W.M., A. Silvis, J.B. Johnson, J.W. Edwards, and M. Karp. 2016a. Northern long-eared bat day-roosting and prescribed fire in the central Appalachians, USA. Fire Ecology 12: 13-27 https://doi.org/10.4996/fireecology.1202013.

Ford, W.M., A. Silvis, J.L. Rodrigue, A.B. Kniowski, and J.B. Johnson. 2016b. Deriving habitat models for northern long-eared bats from historical detection data: a case study using the Fernow Experimental Forest. Journal of Fish and Wildlife Management 7: 86-98 https://doi.org/10.3996/012015-JFWM-004.

Francl, K.E., W.M. Ford, D.W. Sparks, and V. Brack Jr. 2012. Capture and reproductive trends in summer bat communities in West Virginia: assessing the impact of white-nose syndrome. Journal of Fish and Wildlife Management 3: 33-42 https://doi.org/10.3996/062011-JFWM-039.

Frick, W.F., J.F. Pollock, A.C. Hicks, K.E. Langwig, D.S. Reynolds, G.G. Turner, C.M. Butchkoski, and T.H. Kunz. 2010. An emerging disease causes regional population collapse of a common North American bat species. Science 329: 679-682 https://doi.org/10.1126/science.1188594.

Grueber, C.E., S. Nakagawa, R.J. Laws, and I.G. Jamieson. 2011. Multimodel inference in ecology and evolution: challenges and solutions. Journal of Evolutionary Biology 24: 699-711 https://doi.org/10.1111/j.1420-9101.2010. 02210.x.

Hein, C.D., S.B. Castleberry, and K.V. Miller. 2009. Site-occupancy of bats in relation to forested corridors. Forest Ecology and Management 257: 1200-1207 https://doi.org/10.1016/j.foreco.2008.09.054

Hessl, A.E., T. Saladyga, T. Schuler, P. Clark, and J. Wixom. 2011. Fire history from three species on a central Appalachian ridgetop. Canadian Journal of Forest Research 41: 2031-2039 https://doi.org/10.1139/x11-125.

Hutchinson, J.T., and M.J. Lacki. 1999. Foraging behavior and habitat use of red bats in mixed mesophytic forests of the Cumberland Plateau, Kentucky. In Proceedings of the 12th central hardwood forest conference. USDA Forest Service General Technical Report SO-24, ed. J.W. Stringer and D.L. Loftis, 171177. Asheville: Southern Research Station.

Hutchinson, T.F., E.K. Sutherland, and D.A. Yaussy. 2005. Effects of repeated prescribed fires on the structure, composition, and regeneration of mixedoak forests in Ohio. Forest Ecology and Management 218: 210-228 https://doi. org/10.1016/j.foreco.2005.07.011.

Johnson, J.B., J.W. Edwards, and W.M. Ford. 2012. Nocturnal activity patterns of northern myotis (Myotis septentrionalis) during the maternity season in West Virginia (USA). Acta Chiropterologica 13: 391-397 https://doi.org/10.3161/ $150811011 \times 624866$

Johnson, J.B., J.W. Edwards, W.M. Ford, and J.E. Gates. 2009. Roost tree selection by northern myotis (Myotis septentrionalis) maternity colonies following prescribed fire in a central Appalachian Mountains hardwood forest. Forest Ecology and Management 258: 233-242 https://doi.org/10.1016/j.foreco.2009. 04.008

Johnson, J.B., W.M. Ford, J.W. Edwards, and M.A. Menzel. 2010a. Bat community structure within riparian areas of northwestern Georgia, USA. Folia Zoologica 59: 192-202 https://doi.org/10.25225/fozo.v59.i3.a4.2010.
Johnson, J.B., W.M. Ford, J.L. Rodrigue, J.W. Edwards, and C.M. Johnson. $2010 \mathrm{~b}$. Roost selection by male Indiana Myotis following forest fires in central Appalachian hardwoods forests. Journal of Fish and Wildife Management 1: 111-121 https://doi.org/10.3996/042010-JFWM-007.

Kniowski, A.B., and S.D. Gehrt. 2014. Home range and habitat selection of the Indiana bat in an agricultural landscape: home range and habitat use by Indiana bats. Journal of Wildlife Management 78: 503-512. https://doi.org/10 1002/jwmg.677.

Kreye, J.K., J.M. Varner, J.K. Hiers, and J. Mola. 2013. Toward a mechanism for eastern North American forest mesophication: differential litter drying across 17 species. Ecological Applications 23: 1976-1986 https://doi.org/10.1890/130503.1.

Lacki, M.J., D.R. Cox, L.E. Dodd, and M.B. Dickinson. 2009. Response of northern bats (Myotis septentrionalis) to prescribed fires in eastern Kentucky forests. Journal of Mammalogy 90: 1165-1175 https://doi.org/10.1644/08-MAMM-A349.1.

Loeb, S.C., and T.A. Waldrop. 2008. Bat activity in relation to fire and fire surrogate treatments in Southern pine stands. Forest Ecology and Management 255: 3185-3192 https://doi.org/10.1016/j.foreco.2007.10.060.

Mladenoff, D.J., and W.L. Baker. 1999. Spatial modeling of forest landscape change: approaches and applications. Cambridge: Cambridge University Press.

Muthersbaugh, M.S. 2018. Seasonal activity patterns of bats in the central Appalachians. Blacksburg: Thesis, Virginia Polytechnic Institute and State University.

Nocera, T. 2018. Assessing the long-term impacts of white-nose syndrome on bat communities using acoustic surveys at Fort Drum Military Installation. Blacksburg: Thesis, Virginia Polytechnic Institute and State University.

Norberg, U.M., and J.M. Rayner. 1985. Ecological morphology and flight in bats (Mammalia; Chiroptera): wing adaptations, flight performance, foraging strategy and echolocation. Philosophical Transactions of the Royal Society 316: 335-427 https://doi.org/10.1098/rstb.1987.0030

Nowacki, G.J., and M.D. Abrams. 2008. The demise of fire and "mesophication" of forests in the eastern United States. BioScience 58: 123-138 https://doi.org/10. 1641/B580207.

O'Keefe, J.M., S.C. Loeb, P.D. Gerard, and J.D. Lanham. 2013. Effects of riparian buffer width on activity and detection of common bats in the southern Appalachian Mountains: effects of riparian buffers on bats. Wildlife Society Bulletin 37: 319-326 https://doi.org/10.1002/wsb.267.

O'Keefe, J.M., S.C. Loeb, H.S. Hill Jr., and J.D. Lanham. 2014. Quantifying clutter: a comparison of four methods and their relationship to bat detection. Forest Ecology and Management 322: 1-9 https://doi.org/10.1016/j.foreco.2014.02.036.

Owen, S.F., M.A. Menzel, and J.W. Edwards. 2004. Bat activity in harvested and intact forest stands in the Allegheny Mountains. Northern Journal of Applied Forestry 21: 154-159.

Perry, R.W. 2012. A review of fire effects on bats and bat habitat in the Eastern oaks region. In Proceedings of the 4th fire in Eastern oak forests conference. USDA Forest Service General Technical Report NRS-P-102, Northern Research Station, Newtown Square, ed. D.C. Dey, M.C. Stambaugh, S.L. Clark, and C.J. Schweitzer, 170-191.

Philippi, T 2013. GRTS spatial sampling (for monitoring). https://science.nature. nps.gov/im/datamgmt/statistics/r/advanced/grts.cfm\#GRTScall. Accessed 13 Mar 2015.

Ratcliffe, J.M., and J.W. Dawson. 2003. Behavioural flexibility: the little brown bat, Myotis lucifugus, and the northern long-eared bat, M. septentrionalis, both glean and hawk prey. Animal Behaviour 66: 847-856 https://doi.org/10.1006/ anbe.2003.2297.

Reilly, M., K. Outcalt, J. O'Brien, and D. Wade. 2016. Effects of repeated growing season prescribed fire on the structure and composition of pine-hardwood forests in the southeastern Piedmont, USA. Forests 8: 8 https://doi.org/10. 3390/f8010008

Reynolds, R.J., K.E. Powers, W. Orndorff, W.M. Ford, and C.S. Hobson. 2016. Changes in rates of capture and demographics of Myotis septentrionalis (northern long-eared bat) in western Virginia before and after onset of white-nose syndrome. Northeastern Naturalist 23: 195-204 https://doi.org/10. 1656/045.023.0201.

Rogers, D.S., M.C. Belk, M.W. González, and B.L. Coleman. 2006. Patterns of habitat use by bats along a riparian corridor in northern Utah. The Southwestern Naturalist 51: 52-58.

Rudolph, D.C., and C.A. Ely. 2000. The influence of fire on Lepidopteran abundance and community structure in forested habitats of eastern Texas. Texas Journal of Science 52: 127-138. 
Silvis, A., W.M. Ford, and E.R. Britzke. 2015. Effects of hierarchical roost removal on northern long-eared bat (Myotis septentrionalis) maternity colonies. PLoS One 10: e0116356 https://doi.org/10.1371/journal.pone.0116356.

Silvis, A., S.D. Gehrt, and R.A. Williams. 2016a. Effects of shelterwood harvest and prescribed fire in upland Appalachian hardwood forests on bat activity. Forest Ecology and Management 360: 205-212 https://doi.org/10.1016/j. foreco.2015.10.010

Silvis, A., R. Perry, and W.M. Ford. 2016b. Relationships of three species of bats impacted by white-nose syndrome to forest condition and management. In USDA Forest Service General Technical Report SRS-214, Asheville, North Carolina, USA.

Smith, D.A., and S.D. Gehrt. 2010. Bat response to woodland restoration within urban forest fragments. Restoration Ecology 18: 914-923 https://doi.org/10. 1111/j.1526-100X.2009.00538.x.

Symonds, M.R.E., and A. Moussalli. 2011. A brief guide to model selection, multimodel inference and model averaging in behavioural ecology using Akaike's information criterion. Behavioral Ecology and Sociobiology 65: 13-21 https://doi.org/10.1007/s00265-010-1037-6.

USDA Forest Service [US department of Agriculture Forest Service]. 2006. Monongahela National Forest land and resource management plan. http:// www.fs.usda.gov/Internet/FSE_DOCUMENTS/stelprdb5330420.pdf. Accessed 28 Apr 2015.

USFWS [US Fish and Wildlife Service]. 2017. Indiana bat summer survey guidance: automated acoustics bat ID software programs. https:/www.fws.gov/ midwest/endangered/mammals/inba/surveys/inbaAcousticSoftware.html. Accessed 2 May 2017.

Yarnell, S.L. 1998. The southern Appalachians: a history of the landscape. USDA Forest Service General Technical Report SRS-18, Southern Research Station, Asheville.

Zahn, A. 1999. Reproductive success, colony size and roost temperature in atticdwelling bat Myotis myotis. Journal of Zoology 247: 275-280 https://doi.org/ 10.1111/j.1469-7998.1999.tb00991.x.

\section{Submit your manuscript to a SpringerOpen ${ }^{\circ}$ journal and benefit from:}

- Convenient online submission

- Rigorous peer review

- Open access: articles freely available online

High visibility within the field

- Retaining the copyright to your article

Submit your next manuscript at $\boldsymbol{\nabla}$ springeropen.com 